times. It seems to me that it is very likely that the Universe is the creation of a God, but in that case I take the view that the whole grand structure, the bits I think I understand, as well as the bits I certainly don't, are and always have been manifestations of the same intelligence and creating and sustaining power.

On the same basis, although a Creator obviously could at any time or place suspend the "laws of nature" as we have observed them, we can use the method and approach of science only if we assume that these laws operate consistently in time and space. Here the argument echoes that of the "creationists" and "evolutionists" in the USA. It might happen that a scientific examination forced the conclusion that, apart from the existence of the Universe in time and space, some other specific creation events or insertions of genes from space could be demonstrated to have taken place. Hoyle and Wickramasinghe have not convinced me - though my mind is still open.

D.A.J. Tyrrell is Deputy Director of the MRC Clinical Research Centre, Harrow, Middlesex.

\section{To be an astronomer}

\section{Stephen P. Maran}

In Quest of Telescopes. By Martin Cohen. Pp.131. ISBN 0-9333-4625-5. (Sky Publishing, Cambridge, Mass: 1981.) \$11.95.

MARTIN Cohen, an expert on T Tauri stars and cometary nebulae, and an English astronomer in the grand tradition of observation and discovery, has written his " astronomical autobiography", Unashamedly still an amateur at heart, Cohen is one of the diminishing breed of professional astronomers who actually enjoy the view through the eyepiece while they make the arcane measurements of the trade.

The book describes a life-long love of telescopes and star-gazing by way of vignettes drawn mostly from time spent at the major observatories of the American West. A photograph of the awed author, dwarfed by the 200 -inch Hale reflector, is symbolic representation of the principal theme, a paean to the beauty both of the stars and of the great instruments with which we study them. Helicopter rides in the snow-bound White Mountains aside, his travels to pursue observational research at remote sites in North and South America are typical of those of many astronomers of the present generation who, as Cohen says, "have become jet-set commuters".

Although I began ten years before Cohen and on the opposite shore of the Atlantic, I see that we had many corresponding experiences. The young Martin cycled around town to his first small tele- scopes and astronomy club meetings; I rode the New York subway to do the same. He twice mistook an internal reflection for a new comet; I watched a student repeatedly "adjust focus" of a Kitt Peak telescope by tweaking what was in fact the counterweight balance adjustment. We both erected mid-sized telescopes in the mountains near Tucson, and apparently both of us found that large, lightweight aluminium mirrors don't work, regardless of what experts once wrote.

In Quest of Telescopes aims to show high-school students and others what the astronomer's life is like. This is accomplished as much by the brief accounts of how major insights and discoveries were achieved as in the tales of events in Minnesota, Arizona, Chile, California and Hawaii. The book provides a fine description of what it is like to visit and work at a great national observatory. There also are many instructive anecdotes, interspersed with amusing tales fit for telling on cloudy nights while the wind whistles round the dome. Of these, the best is Cohen's recollection of the invasion of an infrared observatory by a horde of moths, who so filled the optical path of the telescope that it was possible to sense their temperature if not, temporarily, that of the stars. I also was glad to find descriptions of the as yet inexplicable problems that intrigue the author, such as the circumstance that large and small stars seemingly are born in separate nurseries. Perhaps a young reader will some day find the answer.

This Quest lacks an account of teaching, which is a major responsibility for so many astronomers. Note also that the young readers inspired by Cohen will find fewer opportunities to enjoy the observatory life than did he; an "observing run" now often means a trip to a prosaic NASA or ESA

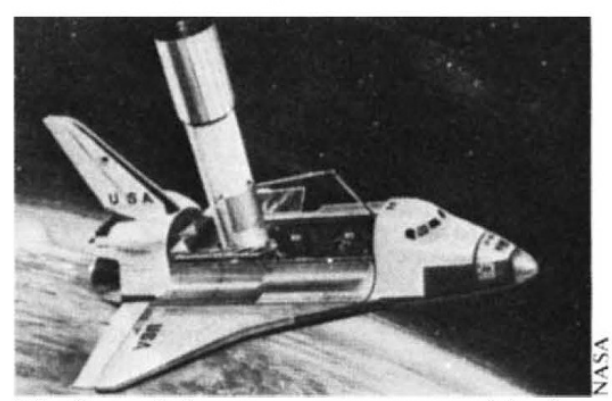

The Space Telescope - new opportunities for astronomers.

satellite control room. Further, in the 1990 s, the data from the major mountainbased telescopes will surely flow to central city terminals or even directly to the "observer's" home institution, and jetsetting will fall off accordingly. High above, however, a few lucky astronomers will be operating their telescopes aboard the Space Shuttle.

Stephen P. Maran, a Senior Staff Scientist in the Laboratory for Astronomy and Solar Physics at the Goddard Space Flight Center, is currently helping to build a spectrograph for the Space Telescope.

\section{The chemists' Earth}

\author{
Peter J. Smith
}

The Earth: Its Birth \& Growth. By Minoru Ozima. Pp.117. ISBN hbk 0-521-23500-6; ISBN pbk 0-521-28005-2. (Cambridge University Press: 1981.) Hbk £10.50, $\$ 22.50$; pbk £3.95, \$8.95.

HERE is a cautionary tale. In 1947 the research vessel Atlantis dredged some metamorphosed basalts from the midAtlantic ridge at $30^{\circ} \mathrm{N}$. When these rocks later came to be dated by the potassiumargon method they were found to be about 48 million years old, far from the roughly zero age they should have had on the basis of the seafloor spreading hypothesis just becoming popular. At the time this little inconsistency was put down to "error" (possibly the presence of excess argon-40, a well known age-invalidating phenomenon) and then conveniently forgotten.

Or rather it was forgotten by almost everyone but Minoru Ozima, who in the late 1960 s had another go at dating the offending samples, this time using the new argon-argon technique with its isochron consistency test. In this way the correct age of the basalt was found to be 170 million years, thus producing even greater consternation involving accusations of specimen mishandling and cries of triumph from the "anti-spreaders". Observation and hypothesis were neatly reconciled in the end, however, by concluding that the basalt must have been left behind at the ridge from the time of the initial split of South America and Africa.

Only a geochemist would have the gall to embarrass the geophysical gods by dragging up this sort of thing; but the simple moral of the anecdote is well taken, namely, that isotope geochemistry has a vital role to play in elucidating the details of plate tectonic processes. What is more, unlike plate tectonic studies, which have hitherto concentrated largely on the past 200 million years, geochemical investigations are crucial in interpreting the whole course of the Earth's evolution. Earth scientists know this already, of course; but for the less specialist reader the more sober geochemical story has tended to fade against the background of the past two decades' blaze of geophysical publicity.

Ozima has set out to correct this unjust imbalance by providing for the general reader a short account of the way in which natural isotope studies have been used to trace the Earth's broad development. Beginning with the "birth of elements" in the nucleosynthesis that preceded the formation of the Solar System, he then looks in turn at the accretion of the Earth as a whole, the formation of the core, the separation of crust and mantle, subsequent changes in the crust, and the origin of the oceans and the atmosphere. The book ends with a discussion of the ways in which man- 